\title{
A DEMATEL Method to Analyze the Barriers of Supply Chain Management in Food Processing Industry
}

\author{
S. Bathrinath, R.K.A. Bhalaji, S. Sivakumar, S. Tamilazhagan, S. Vinothkumar
}

\begin{abstract}
In food processing industry, implementation of supply chain management (SCM) is confronting and complex one by involving different barriers because if affects the performance of organization. If some barriers are noticed, observed and recognized it can be reduced. The objective of the paper is to recognize the barriers by risk assessment. Risk assessment in an industry can help supply chain managers to choose effective decision of the problems. This research proposes a case study conducted on the leading food processing industry in southern region of India. In this paper, to analyze the barriers by using hybrid multi-criteria decision making method like Decision making trial and evaluation laboratory (DEMATEL). Barriers collected from the literature survey were used to evaluate the most influential barriers of supply chain management with the assist of industrial experts. The suggested framework was validated with case industry and the results are compared with the existing literatures and comments from experts. Also, this paper finishes with an assessment of own drawbacks beside the identification of useful managerial implications; it depicts future developments possible in the process of supply chain management in the context of India.
\end{abstract}

Keywords: DEMATEL, India, SCM.

\section{INTRODUCTION}

$\mathrm{F}_{\text {or the improvement of company performance as well as }}$ turnover, supply chain management plays a major part in the food processing industry. Supply chain management is the function of flow of services and goods from initial phase to consumer [1]. SCM aids to minimize the stock, improve trust and sharing of proper information between supply chain associates [2]. To secure a competitive advantage, SCM has turned out to be a key manner [3]. But many barriers involved in supply chain management both internal and external part of the industry. It is tough to control and reduce the barriers. To overcome these barriers, industry can implement the SCM. It

Revised Manuscript Received on December 5, 2019

* Correspondence Author

S.Bathrinath* Department of mechancical engineering, Kalasalingam Academy of research and education, Krishnankoil-626126, India. Email: bathri@gmail.com

R.K.A.Bhalaji, Department of mechancical engineering, Kalasalingam Academy of research and education, Krishnankoil-626126, India. Email: bhalaji28@gmail.com

S.Sivakumar, Department of mechancical engineering, Kalasalingam Academy of research and education, Krishnankoil-626126, India. Email: sivas7727@gmail.com

S.Tamilazhagan, Department of mechanical engineering, Kalasalingam Academy of research and education, krishnankoil - 626126, India. Email: tami1457998@gmail.com

S.Vinothkumar, Department of mechanical engineering, Kalasalingam Academy of research and education, krishnankoil-626126, India. Email: sabarivinoth816@gmail.com requires the identification of barriers for the effective implementation. The main aim of the paper is to identify the barriers from literature survey as well as industrial expert's inputs. To analyse the barriers of supply chain management in food processing industry by using MCDM method like DEMATEL. Industrial managers will use our outcomes for reducing the barriers as well as effective implementation of SCM.

\section{LITERATURE SURVEY}

To classify the relevant literature into three sub-sections namely A) Barriers involved in supply chain management B) Using MCDM method for recognizing the barriers in supply chain management C) Literature gap

\section{A. Barriers involved in supply chain management}

Luo et al. [4] investigated the factors for accomplishing the excellence of supply chain management in the context of New Zealand. The findings of the study showed that culture of supply chain and knowledge of supply chain management is the most influential factors between the others. Zhu and Geng [5] analysed the barriers of supply chain management in china manufacturing company. Lack of financial gains, capability and resource are the important barriers in the implementation of supply chain management (SCM) are displayed in the results and they need to implement the SCM without barriers. Lam [6] examined the supply chain management barriers and their relationships. The outcomes revealed that barriers like inventory management and service of customer affecting the SCM and also individualism is the critical barriers for influencing the SCM. Fawcett et al. [7] conducted the case study for analysing the barriers, connections and advantages of effective SCM. The result depicts that measurement systems, technology and information are the key barriers for effective SCM and they suggest managers and practitioners from industry can use our results for the effective implementation of SCM. Manzouri et al. [8] explored the barriers of SCM implementation in both Malaysian and Iranian manufacturing companies by using the software SPSS. The consequences depict that lack of awareness and information about SCM is the most significant barriers for implementation of SCM and they need to implement the barriers.

B. Using MCDM methods for recognizing the barriers in SCM

Kabra and Ramesh [9] examined the drivers of SCM in the context of India by using Fuzzy AHP and TOPSIS. Long term focussed planning is the crucial barrier for SCM and they want to reduce the barriers for the improvement of SCM are shown in the result of this paper. Mangla et al.

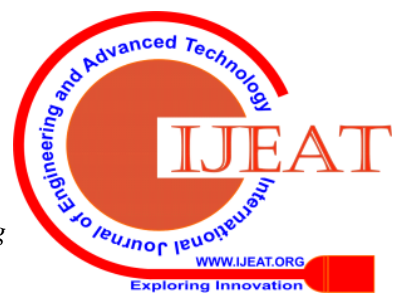


[10] investigated the barriers for achieving the performance SCM under fuzzy environment and to validate the results by using sensitivity analysis. The outcomes demonstrated that organizational barriers get the highest rank among the other barriers for achieving the performance of SCM. Luthra et al. [11] assessed the SCM implementation barriers by using AHP technique. The findings of the paper displayed that government support and polices obtain the highest priority among others and managers for industries will our results for taking the proper decisions for the implementation of SCM. Xia et al. [12] explored the internal barriers of SCM in Chinese automotive spare parts Remanufacturers Company by using the grey DEMATEL approach. The results showed that they eliminated the barriers by using this approach and they have practicing another chances of producing spare parts.

\section{Literature gap}

Based on the literature survey, there is no research paper related to analysing the barriers of supply chain management in food processing industry by using DEMATEL method. To fulfil this gap, we analysed the barriers by using DEMATEL method. Barriers are identified from literature survey as well as inputs from industrial experts and shown in Table 1.

\section{Table- I. List of barriers}

\begin{tabular}{|c|c|c|}
\hline S.No & Barriers & Notation \\
\hline 1 & Transportation systems & B1 \\
\hline 2 & Inefficient chain of traders & $\mathrm{B} 2$ \\
\hline 3 & Absent of sheltered storage & B3 \\
\hline 4 & Absent of cold storage & B4 \\
\hline 5 & Poor food packing & B5 \\
\hline 6 & Hybrid fruits and vegetables & B6 \\
\hline 7 & Population increase & B7 \\
\hline 8 & Traffic jam & B8 \\
\hline 9 & $\begin{array}{l}\text { Waste due to leakages at shop } \\
\text { floor }\end{array}$ & B9 \\
\hline 10 & High production down time & B10 \\
\hline 11 & $\begin{array}{l}\text { Lack of automation and out dated } \\
\text { technology }\end{array}$ & B11 \\
\hline 12 & Over processing & B12 \\
\hline 13 & Improper demand forecast & B13 \\
\hline 14 & Unbalanced production time & B14 \\
\hline 15 & Quality issue & $\mathrm{B} 15$ \\
\hline 16 & More waiting at packing time & B16 \\
\hline 17 & Lack of water & B17 \\
\hline 18 & Adding chemical & B18 \\
\hline
\end{tabular}

\section{FRAMEWORK OF THE PAPER}

Figure 1 shows the flowchart of the paper.

\section{METHODOLOGY}

DEMATEL method is used to examine the waste of supply chain management in food processing industry is the objective of this paper.

\section{A. DEMATEL}

It is a traditional tool for solving any complicated problems in industries and also to investigate the relationships among each and every barrier. For solving the problem, recently many researchers used DEMATEL method $[13,14]$.

The procedures of DEMATEL method are discussed below [15].

Phase 1: To calculate the matrix for initial direct relation ' $E$ ' Based on the inputs of decision makers, to contrast and analyse the barriers for building the matrix of ' $E$ '. For the ' $E$ ' matrix, mathematical formulation is provided below. $E=\left[\begin{array}{llllll}1 & E_{12} & E_{13} & \ldots & E_{1(n-1)} & E_{1 n} \\ E_{21} & 1 & E_{23} & \ldots & E_{2(n-1)} & E_{2 n} \\ \ldots & \ldots & \ldots & \ldots & \ldots & \ldots \\ \ldots & \ldots & \ldots & \ldots & \ldots & \ldots \\ E_{(n-1) 1} & E_{(n-1) 2} & E_{(n-1) 3} & \ldots & 1 & E_{(n-1) 1} \\ E_{n 1} & E_{n 2} & E_{n 3} & \ldots & E_{n(n-1)} & 1\end{array}\right](1)$

For analyzing the barriers, this paper used the linguistic scale and is exhibited in Table 2.

Table- II. Linguistic scale

\begin{tabular}{|c|c|}
\hline Score & Variable \\
\hline 4 & Very high impact \\
\hline 3 & High impact \\
\hline 2 & Low impact \\
\hline 1 & Very low impact \\
\hline 0 & No impact \\
\hline
\end{tabular}

Inputs are gathered from decision makers and they give rating for barriers by using questionnaire.

Phase 2: To Normalize the 'E' matrix (G)

$$
\begin{aligned}
F & =\frac{1}{\max _{1 \leq i \leq n}} \sum_{j-1}^{n} E_{i j} \\
G & =F \times E
\end{aligned}
$$

Phase 3: To calculate the matrix for Total relation ' $\mathrm{H}$ '

$$
H=G(I-G)^{-1}
$$

Phase 4: To calculate the sum of rows and columns

By using equations (5) and (6), to calculate the sum of rows and columns and indicated as $r w_{i}$ and $c w_{i}$ respectively.

$$
\begin{aligned}
& r w_{i}=\left[\sum_{j-1}^{n} E_{i j}\right]_{n \times 1} \\
& c w_{i}=\left[\sum_{i=1}^{n} E_{i j}\right]_{1 \times n}
\end{aligned}
$$

Phase 5: Causal figure

The causal figure is created and to map the horizontal and vertical axes of the graph by using the values of both $r w_{i}$ and $c w_{i}$. To describe the relationship between every barriers and most influential barrier in the food processing industry are depicted in causal figure.

\section{CASE STUDY}

In this paper, case study is conducted in food processing industry and they are the leading one in southern region of India. Over 500 workers are employed in the industry with the annual turnover of 50 crores. Nowadays, organization growth is increasing rapidly and acquired new markets. Because of increasing customer demands, they faced lot of problems and stresses. Within the quick time, they manufacture and supply the product to the customer. 
Due to these reasons, many barriers are involved in the supply chain management. It affects distribution of products to the customer. Here, risk assessment is required to control the barriers and also identifying the most influential barrier in the supply chain management. This paper suggested the DEMATEL method for analyzing the barriers. A team of decision makers like chief manager, chief engineer and supply chain manager is formed for assessing and recognizing the most influential barrier. Industrial managers will use our outcomes to understand the barriers of supply chain management, for reducing or controlling the barriers and also the implementation of supply chain management. The scope diagram of the paper is presented in Fig 2.

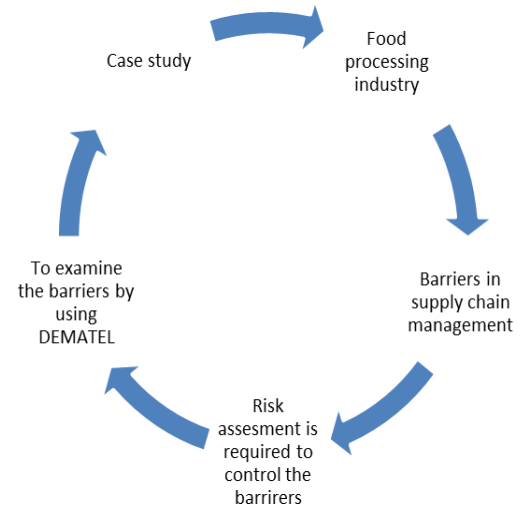

Fig. 2. Scope diagram of the paper

\section{RESULT AND DISCUSSIONS}

This paper used the DEMATEL method for recognizing the most influential barriers of supply chain management in the food processing industry. For the past decade, it is difficult to face and control the barriers of supply chain management. Seventeen barriers are investigates in this paper and DEMATEL method is used to examine the interrelationships with every barrier. Based on the causal diagram this paper was handled and it is shown in Fig3.

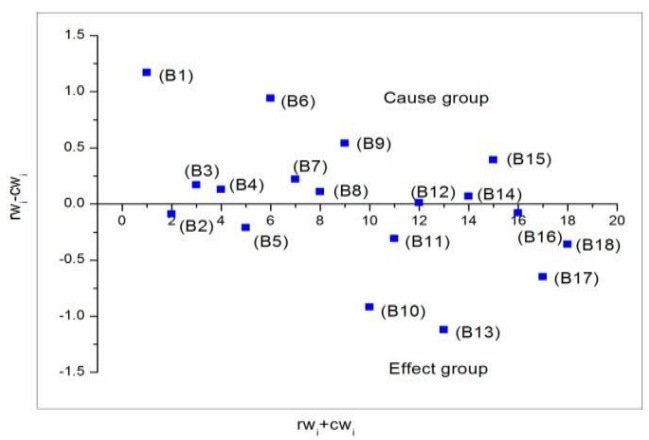

Fig. 3. Causal diagram

\section{A. Discussion of cause group barriers}

In every organization, it is challenging to concentrate various barriers among them and also all cause group barriers are the most important one. From the causal diagram, Transportation systems (B1) is the most influential barriers between other barriers has a maximum $\left(r w_{i}-c w_{i}\right)$ value of 1.17 and it has $\left(r w_{i}+c w_{i}\right)$ value of 5.05 is in the intermediate range and depicts low influence. To transport the food from production line to the customer without affecting the food by global warming as well as environment. Therefore they need to reduce the distant of food travels otherwise to implement the smart transportation systems. The second one in the cause group is hybrid fruits and vegetables (B6) with $\left(r w_{i}-c w_{i}\right)$ value of 0.94 with the corresponding value $\left(r w_{i}+c w_{i}\right)$ of 3.88 . They are made by certain specification of fruits and vegetables and it creates some new variety of products. To make new cultivars are produced by using propagation of plants. For the supply chain process, to avoid the hybrid fruits and vegetables because it easily affects by moisture and also more rotten. Waste due to leakages at shop floor (B9) is third one in the cause group has a $\left(r w_{i}-c w_{i}\right)$ value of 0.54 with the equivalent $\left(r w_{i}+c w_{i}\right)$ value of 4.34 In the shop floor, some wastes are created mainly due to spill or leak of chemicals it affects the supply chain process. Therefore, effective disposal and store management is needed to control the leakages. The sequence of order of other barriers in the cause group is quality issue (B15), population increase (B7), absent of sheltered storage (B3), absent of cold storage (B4), traffic jam (B8), unbalanced production time (B14) with $\left(r w_{i}-c w_{i}\right)$ value of $0.39,0.22,0.17,0.13$ and 0.11 . The last one in the cause group are over-processing (B12) with $\left(r w_{i}-c w_{i}\right)$ value of 0.01 . To manufacture the product before it requires and also it has some sort of waste. They required manufacturing the product based on the needs of customer.

\section{B. Discussion of effect group barriers}

The most influential barrier in the effect group is more waiting at packing time (B16) with $\left(r w_{i}-c w_{i}\right)$ value of -0.08 . In the supply chain management, packing always takes more time to complete the process not more than three weeks. Proper packing station is needed by the industry for the process of fast packing and also increases the shift for employees at the time of packing. Inefficient chain of traders (B2) is the second one in the effect group with $\left(r w_{i}-c w_{i}\right)$ value of -0.09 . Some organization does not have proper supply chain between company and traders it affects the efficiency of supply chain process. Therefore diminishing the supply chain inefficiencies by both raising the investments as well as maintaining the relationship between traders. Poor food packing (B5) has a $\left(r w_{i}-c w_{i}\right)$ value of -0.21 are the third one in the effect group. To pack the food by some protection and resistance in the cover and it includes some contents about nutrition level. Some organization does not pack the food based on the needs of biological, chemical and physical terms and it is mandatory to provide the label of expiry date of products. The order of sequence of other barriers in the effect group is lack of automation and automated technology (B11), traffic jam (B8), lack of water (B17), high production down time (B10) and improper demand forecast (B13) with $\left(r w_{i}-c w_{i}\right)$ value of $-0.31,-0.36,-0.65,-0.92$ and -1.12 . 


\section{CONCLUSION}

Every organization faced barriers of supply chain management but they easy to control by using some methods. But in the food processing industry, it is difficult to control the barriers. They use some traditional tools for examining barriers of supply chain management based on the restriction of time but it is a complex task to manage it. To examine the barriers of supply chain management by using the suggested DEMATEL method for solving this issue. To analyze the interrelationships between barriers and to identify the most influential barrier in the food processing industry by using this method. Based on the figure 2, transportation systems (B1) plays a key role in the food processing industry and also it is the most influential one. To implement the smart transportation systems as well as reduce the distance of time travels. For implementing the supply chain management as well as reducing the barriers, industrial mangers will use our outcomes. This paper has some drawbacks as well as that can be investigated in the future. For example, some barriers may not have good bonding relationship with other barriers because analysis of barriers is considered on one barriers influence over other barriers. Other MCDM methods like AHP, ANP and VIKOR may have good relationship features for solving these drawbacks and limited number of decision maker's opinion is used in the paper. To generate the structural model and to ensure the expansion of this work, increasing the no of decision maker's opinion for the future perspective.

\section{REFERENCES}

1. V. Parmar and H. G. Shah, "A literature review on supply chain management barriers in manufacturing organization," International Journal of Engineering Development and Research, Vol. 4(1), 2016 , 26-42.

2. S. J. Gorane and R. Kant, "Modelling the SCM implementation barriers: An integrated ISM-fuzzy MICMAC approach," Journal of Modelling in Management, Vol. 10(2), 2016, 158-178.

3. K. Govindan, M. Kaliyan, D. Kannan and A. N. Haq, "Barriers analysis for green supply chain management implementation in Indian industries using analytic hierarchy process," International Journal of Production Economics, Vol. 147, 2014, 555-568.

4. W. Luo, Y. Shi and V. G. Venkatesh, "Exploring the factors of achieving supply chain excellence: a New Zealand perspective," Production Planning \& Control, Vol. 29(8), 2016, 655-667.

5. Q. Zhu and Y. Geng, "Drivers and barriers of extended supply chain practices for energy saving and emission reduction among Chinese manufacturers," Journal of Cleaner Production, Vol. 40, 2016, 6-12.

6. M. A. Patwary, W. T. O'Hare, G. Street, K. M. Elahi, S. S. Hossain and M. H. Sarker, "Quantitative assessment of medical waste generation in the capital city of Bangladesh," Waste management, Vol. 29(8), 2019, 2392-2397.

7. S. E. Fawcett, G. M. Magnan and M. W. McCarter, "Benefits, barriers, and bridges to effective supply chain management," Supply Chain Management: An International Journal, Vol. 13(1), 2018, 35-48.

8. M. Manzouri, M. N. A. Rahman, H. Arshad and A. R. Ismail, "Barriers of supply chain management implementation in manufacturing companies: a comparison between Iranian and Malaysian companies," Journal of the Chinese Institute of Industrial Engineers, Vol. 27(6), 2010, 456-472.

9. G. Kabra and A. Ramesh, "Analyzing drivers and barriers of coordination in humanitarian supply chain management under fuzzy environment," Benchmarking: An International Journal, Vol. 22(4), 2015, 559-587.

10. S. K. Mangla, K. Govindan and S. Luthra, "Prioritizing the barriers to achieve sustainable consumption and production trends in supply chains using fuzzy Analytical Hierarchy Process," Journal of cleaner production, Vol. 151, 2017, 509-525.
11. S. Luthra, S. K. Mangla, L. Xu and A. Diabat, "Using AHP to evaluate barriers in adopting sustainable consumption and production initiatives in a supply chain," International Journal of Production Economics, Vol. 181, 2016, 342-349.

12. X. Xia, K. Govindan and Q. Zhu, "Analyzing internal barriers for automotive parts remanufacturers in China using grey-DEMATEL approach," Journal of Cleaner Production, Vol. 87, 2015, 811-825.

13. S. Bathrinath, V. S. Charan, S. G. Ponnambalam and S. Saravanasankar, "Identification and Evaluation of Criteria of Agile Manufacturing Using DEMATEL: A Case from an Indian Metal Fabrication Industry,” Journal of Modern Manufacturing Systems and Technology, Vol. 2(1), 2015, 61-74.

14. R. K. A. Bhalaji, S. Bathrinath, S. G. Ponnambalam and S. Saravanasankar, "A Fuzzy Decision-Making Trial and Evaluation Laboratory approach to analyse risk factors related to environmental health and safety aspects in the healthcare industry," Sādhanā, Vol. 44(3), 2019, 55.

15. L. Zhang, X.Sun and H. Xue, "Identifying critical risks in Sponge City PPP projects using DEMATEL method: a case study of China," Journal of Cleaner Production, 2019.

\section{AUTHORS PROFILE}

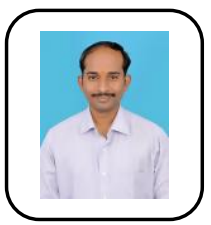

Dr.S.Bathrinath is an Associate Professor in the Department of Mechanical Engineering, Kalasalingam Academy of Research and Education, Krishnankoil, Tamilnadu, India. His current area of research includes multi-criteria decision making, scheduling \& optimization, soft computing and Artificial intelligence. He has published a number of papers in journal of national/international repute and presented a number of papers in various conferences/symposia in India and abroad. He is presently guiding a number of master/doctoral research scholars. Dr.S.Bathrinath is the corresponding author and can be contacted at: bathri@gmail.com

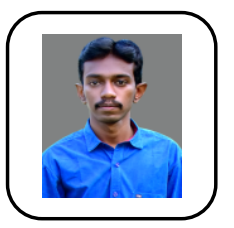

R.K.A.Bhalaji obtained his B.E (MECH) in 2014 from the K.L.N.College of Engineering, Madurai, Tamilnadu, India. He completed his M.Tech (Industrial Safety Engineering) in 2016 at the Kalasalingam Academy of Research and Education, Krishnankoil, Tamilnadu, India. Currently, he is a Research Scholar in the Department of Mechanical Engineering, Kalasalingam Academy of Research and Education, Krishnankoil, Tamilnadu, India. His research interests include multi-criteria decision making and application of fuzzy set theory in real life decision problems. He is currently pursuing PHD in the area of analysis of risk factors for the identification and evaluation for finding influential risk factors in healthcare industries by using MCDM methods.

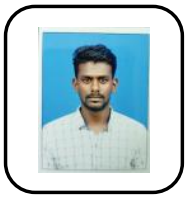

S. Sivakumar is currently doing final year B.E(MECH) in kalasalingam academy of research and education, Krishankovil,,Tamilnadu,India.

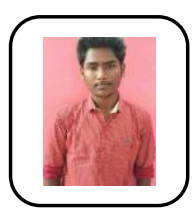

S.Tamilazhagan is currently doing final year B.E(MECH) in kalasalingam academy of research and education, Krishankoil, Tamilnadu, India.

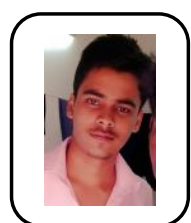

S.Vinothkumar is currently doing final year B.E $(\mathrm{MECH})$ in kalasalingam academy of research and education, krishnankoil, Tamilnadu, India. 


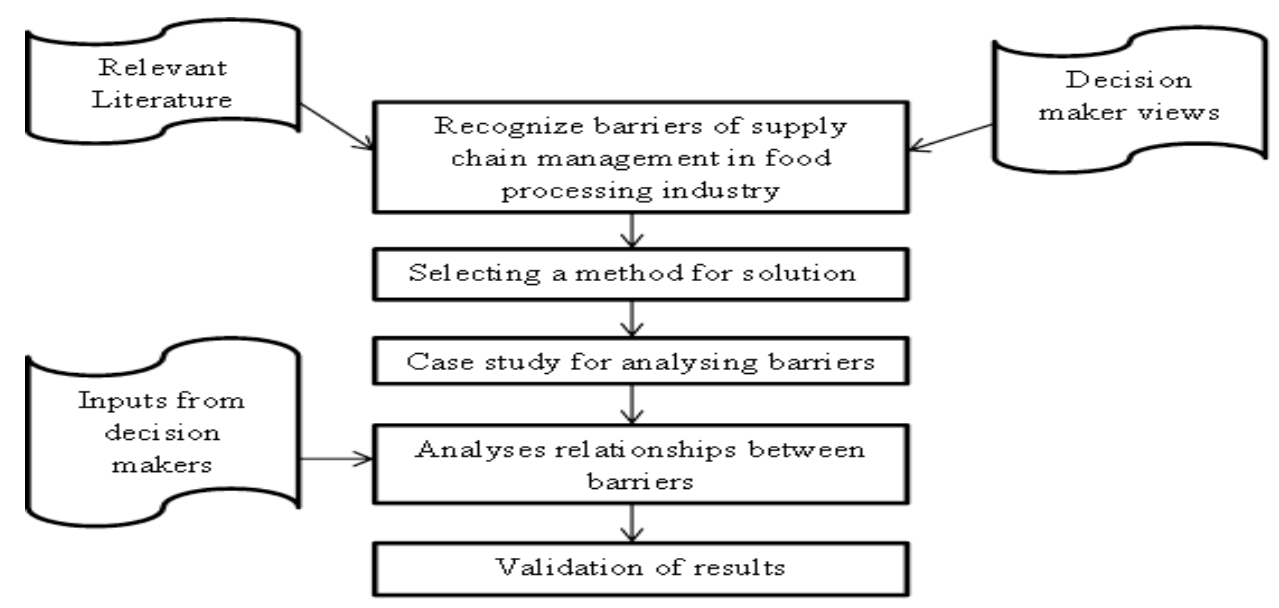

FIGURE1. FRAMEWORK OF THE PAPER

Table- III. Initial DRM

\begin{tabular}{|c|c|c|c|c|c|c|c|c|c|c|c|c|c|c|c|c|c|c|}
\hline & B1 & B2 & B3 & B4 & B5 & B6 & B7 & B8 & B9 & B10 & B11 & B12 & B13 & B14 & B15 & B16 & B17 & $\begin{array}{l}\text { B1 } \\
8\end{array}$ \\
\hline B1 & 0 & 3 & 2 & 2 & 3 & 1 & 3 & 3 & 2 & 3 & 2 & 3 & 4 & 2 & 2 & 3 & 1 & 3 \\
\hline B2 & 2 & 0 & 3 & 3 & 4 & 2 & 0 & 1 & 1 & 2 & 2 & 1 & 3 & 2 & 3 & 2 & 2 & 3 \\
\hline B3 & 2 & 2 & 0 & 2 & 3 & 1 & 2 & 1 & 3 & 3 & 1 & 2 & 4 & 2 & 3 & 2 & 3 & 2 \\
\hline B4 & 2 & 2 & 0 & 0 & 3 & 1 & 2 & 1 & 4 & 3 & 1 & 2 & 3 & 2 & 3 & 2 & 3 & 2 \\
\hline B5 & 3 & 2 & 0 & 2 & 0 & 1 & 3 & 2 & 0 & 3 & 2 & 2 & 3 & 1 & 3 & 4 & 2 & 3 \\
\hline B6 & 1 & 1 & 2 & 1 & 3 & 0 & 2 & 3 & 0 & 0 & 1 & 0 & 2 & 2 & 3 & 2 & 2 & 3 \\
\hline B7 & 3 & 3 & 2 & 2 & 3 & 1 & 0 & 2 & 1 & 3 & 3 & 2 & 4 & 2 & 3 & 3 & 4 & 3 \\
\hline B8 & 1 & 1 & 2 & 2 & 0 & 0 & 3 & 0 & 2 & 3 & 0 & 2 & 3 & 0 & 0 & 2 & 0 & 0 \\
\hline B9 & 2 & 2 & 2 & 3 & 4 & 0 & 0 & 3 & 0 & 3 & 1 & 1 & 0 & 0 & 3 & 2 & 1 & 0 \\
\hline B10 & 0 & 3 & 3 & 1 & 0 & 0 & 4 & 0 & 0 & 0 & 3 & 0 & 1 & 4 & 1 & 0 & 0 & 0 \\
\hline B11 & 1 & 2 & 1 & 2 & 3 & 0 & 4 & 2 & 1 & 1 & 0 & 0 & 4 & 2 & 1 & 0 & 0 & 0 \\
\hline B12 & 0 & 3 & 2 & 1 & 4 & 0 & 0 & 0 & 1 & 4 & 3 & 0 & 3 & 2 & 1 & 0 & 1 & 1 \\
\hline B13 & 0 & 2 & 3 & 1 & 2 & 0 & 4 & 0 & 1 & 1 & 1 & 3 & 0 & 1 & 2 & 0 & 2 & 0 \\
\hline B14 & 0 & 2 & 4 & 2 & 0 & 0 & 4 & 0 & 0 & 4 & 3 & 2 & 4 & 0 & 0 & 1 & 2 & 1 \\
\hline B15 & 0 & 2 & 3 & 4 & 4 & 0 & 1 & 0 & 0 & 4 & 4 & 3 & 4 & 3 & 0 & 2 & 3 & 1 \\
\hline B16 & 1 & 3 & 2 & 1 & 2 & 0 & 0 & 1 & 0 & 3 & 4 & 1 & 2 & 3 & 1 & 0 & 1 & 0 \\
\hline B17 & 0 & 2 & 2 & 2 & 1 & 0 & 3 & 2 & 1 & 0 & 0 & 1 & 0 & 0 & 0 & 1 & 0 & 2 \\
\hline B18 & 0 & 3 & 1 & 2 & 0 & 2 & 1 & 0 & 0 & 0 & 0 & 1 & 0 & 0 & 3 & 1 & 2 & 0 \\
\hline
\end{tabular}

Table- IV. TRM

\begin{tabular}{|c|c|c|c|c|c|c|c|c|c|c|c|c|c|c|c|c|c|c|}
\hline & B1 & B2 & B3 & B4 & B5 & B6 & B7 & B8 & B9 & B10 & B11 & B12 & B13 & B14 & B15 & B16 & B17 & B18 \\
\hline B1 & $\begin{array}{l}1.0 \\
4\end{array}$ & $\begin{array}{l}0.1 \\
5\end{array}$ & $\begin{array}{l}0.1 \\
2\end{array}$ & $\begin{array}{l}0.1 \\
2\end{array}$ & $\begin{array}{l}0.1 \\
5\end{array}$ & $\begin{array}{l}0.0 \\
4\end{array}$ & $\begin{array}{l}0.1 \\
5\end{array}$ & $\begin{array}{l}0.1 \\
0\end{array}$ & $\begin{array}{l}0.0 \\
8\end{array}$ & $\begin{array}{l}0.1 \\
6\end{array}$ & $\begin{array}{l}0.1 \\
2\end{array}$ & $\begin{array}{l}0.1 \\
2\end{array}$ & $\begin{array}{l}0.2 \\
0\end{array}$ & $\begin{array}{l}0.1 \\
1\end{array}$ & $\begin{array}{l}0.1 \\
2\end{array}$ & $\begin{array}{l}0.1 \\
2\end{array}$ & $\begin{array}{l}0.0 \\
9\end{array}$ & $\begin{array}{l}0.1 \\
1\end{array}$ \\
\hline B2 & $\begin{array}{l}0.0 \\
8\end{array}$ & $\begin{array}{l}1.0 \\
8\end{array}$ & $\begin{array}{l}0.1 \\
3\end{array}$ & $\begin{array}{l}0.1 \\
3\end{array}$ & $\begin{array}{l}0.1 \\
7\end{array}$ & $\begin{array}{l}0.0 \\
6\end{array}$ & $\begin{array}{l}0.0 \\
9\end{array}$ & $\begin{array}{l}0.0 \\
6\end{array}$ & $\begin{array}{l}0.0 \\
6\end{array}$ & $\begin{array}{l}0.1 \\
2\end{array}$ & $\begin{array}{l}0.1 \\
1\end{array}$ & $\begin{array}{l}0.0 \\
8\end{array}$ & $\begin{array}{l}0.1 \\
6\end{array}$ & $\begin{array}{l}0.1 \\
0\end{array}$ & $\begin{array}{l}0.1 \\
3\end{array}$ & $\begin{array}{l}0.1 \\
0\end{array}$ & $\begin{array}{l}0.1 \\
0\end{array}$ & $\begin{array}{l}0.1 \\
1\end{array}$ \\
\hline B3 & $\begin{array}{l}0.0 \\
8\end{array}$ & $\begin{array}{l}0.1 \\
2\end{array}$ & $\begin{array}{l}1.0 \\
8\end{array}$ & $\begin{array}{l}0.1 \\
1\end{array}$ & $\begin{array}{l}0.1 \\
5\end{array}$ & $\begin{array}{l}0.0 \\
4\end{array}$ & $\begin{array}{l}0.1 \\
3\end{array}$ & $\begin{array}{l}0.0 \\
6\end{array}$ & $\begin{array}{l}0.1 \\
0\end{array}$ & $\begin{array}{l}0.1 \\
5\end{array}$ & $\begin{array}{l}0.0 \\
9\end{array}$ & $\begin{array}{l}0.1 \\
0\end{array}$ & $\begin{array}{l}0.1 \\
9\end{array}$ & $\begin{array}{l}0.1 \\
0\end{array}$ & $\begin{array}{l}0.1 \\
3\end{array}$ & $\begin{array}{l}0.1 \\
0\end{array}$ & $\begin{array}{l}0.1 \\
3\end{array}$ & $\begin{array}{l}0.0 \\
9\end{array}$ \\
\hline B4 & $\begin{array}{l}0.0 \\
8\end{array}$ & $\begin{array}{l}0.1 \\
2\end{array}$ & $\begin{array}{l}0.0 \\
7\end{array}$ & $\begin{array}{l}1.0 \\
7\end{array}$ & $\begin{array}{l}0.1 \\
4\end{array}$ & $\begin{array}{l}0.0 \\
4\end{array}$ & $\begin{array}{l}0.1 \\
2\end{array}$ & $\begin{array}{l}0.0 \\
6\end{array}$ & $\begin{array}{l}0.1 \\
2\end{array}$ & $\begin{array}{l}0.1 \\
4\end{array}$ & $\begin{array}{l}0.0 \\
9\end{array}$ & $\begin{array}{l}0.0 \\
9\end{array}$ & $\begin{array}{l}0.1 \\
5\end{array}$ & $\begin{array}{l}0.1 \\
0\end{array}$ & $\begin{array}{l}0.1 \\
2\end{array}$ & $\begin{array}{l}0.0 \\
9\end{array}$ & $\begin{array}{l}0.1 \\
2\end{array}$ & $\begin{array}{l}0.0 \\
9\end{array}$ \\
\hline B5 & $\begin{array}{l}0.0 \\
9\end{array}$ & $\begin{array}{l}0.1 \\
2\end{array}$ & $\begin{array}{l}0.0 \\
7\end{array}$ & $\begin{array}{l}0.1 \\
1\end{array}$ & $\begin{array}{l}1.0 \\
8\end{array}$ & $\begin{array}{l}0.0 \\
4\end{array}$ & $\begin{array}{l}0.1 \\
4\end{array}$ & $\begin{array}{l}0.0 \\
8\end{array}$ & $\begin{array}{l}0.0 \\
4\end{array}$ & $\begin{array}{l}0.1 \\
4\end{array}$ & $\begin{array}{l}0.1 \\
1\end{array}$ & $\begin{array}{l}0.0 \\
9\end{array}$ & $\begin{array}{l}0.1 \\
5\end{array}$ & $\begin{array}{l}0.0 \\
8\end{array}$ & $\begin{array}{l}0.1 \\
2\end{array}$ & $\begin{array}{l}0.1 \\
4\end{array}$ & $\begin{array}{l}0.1 \\
0\end{array}$ & $\begin{array}{l}0.1 \\
1\end{array}$ \\
\hline B6 & $\begin{array}{l}0.0 \\
5\end{array}$ & $\begin{array}{l}0.0 \\
8\end{array}$ & $\begin{array}{l}0.0 \\
9\end{array}$ & $\begin{array}{l}0.0 \\
7\end{array}$ & $\begin{array}{l}0.1 \\
2\end{array}$ & $\begin{array}{l}1.0 \\
2\end{array}$ & $\begin{array}{l}0.1 \\
0\end{array}$ & $\begin{array}{l}0.0 \\
9\end{array}$ & $\begin{array}{l}0.0 \\
3\end{array}$ & $\begin{array}{l}0.0 \\
7\end{array}$ & $\begin{array}{l}0.0 \\
7\end{array}$ & $\begin{array}{l}0.0 \\
5\end{array}$ & $\begin{array}{l}0.1 \\
2\end{array}$ & $\begin{array}{l}0.0 \\
8\end{array}$ & $\begin{array}{l}0.1 \\
1\end{array}$ & $\begin{array}{l}0.0 \\
8\end{array}$ & $\begin{array}{l}0.0 \\
9\end{array}$ & $\begin{array}{l}0.1 \\
0\end{array}$ \\
\hline B7 & $\begin{array}{l}0.1 \\
0\end{array}$ & $\begin{array}{l}0.1 \\
5\end{array}$ & $\begin{array}{l}0.1 \\
3\end{array}$ & $\begin{array}{l}0.1 \\
2\end{array}$ & $\begin{array}{l}0.1 \\
6\end{array}$ & $\begin{array}{l}0.0 \\
4\end{array}$ & $\begin{array}{l}1.1 \\
0\end{array}$ & $\begin{array}{l}0.0 \\
9\end{array}$ & $\begin{array}{l}0.0 \\
6\end{array}$ & $\begin{array}{l}0.1 \\
6\end{array}$ & $\begin{array}{l}0.1 \\
4\end{array}$ & $\begin{array}{l}0.1 \\
1\end{array}$ & $\begin{array}{l}0.2 \\
0\end{array}$ & $\begin{array}{l}0.1 \\
1\end{array}$ & $\begin{array}{l}0.1 \\
4\end{array}$ & $\begin{array}{l}0.1 \\
2\end{array}$ & $\begin{array}{l}0.1 \\
6\end{array}$ & $\begin{array}{l}0.1 \\
2\end{array}$ \\
\hline B8 & $\begin{array}{l}0.0 \\
4\end{array}$ & $\begin{array}{l}0.0 \\
7\end{array}$ & $\begin{array}{l}0.0 \\
8\end{array}$ & $\begin{array}{l}0.0 \\
8\end{array}$ & $\begin{array}{l}0.0 \\
5\end{array}$ & $\begin{array}{l}0.0 \\
1\end{array}$ & $\begin{array}{l}0.1 \\
1\end{array}$ & $\begin{array}{l}1.0 \\
2\end{array}$ & $\begin{array}{l}0.0 \\
6\end{array}$ & $\begin{array}{l}0.1 \\
1\end{array}$ & $\begin{array}{l}0.0 \\
4\end{array}$ & $\begin{array}{l}0.0 \\
7\end{array}$ & $\begin{array}{l}0.1 \\
2\end{array}$ & $\begin{array}{l}0.0 \\
4\end{array}$ & $\begin{array}{l}0.0 \\
4\end{array}$ & $\begin{array}{l}0.0 \\
7\end{array}$ & $\begin{array}{l}0.0 \\
4\end{array}$ & $\begin{array}{l}0.0 \\
3\end{array}$ \\
\hline B9 & $\begin{array}{l}0.0 \\
7\end{array}$ & $\begin{array}{l}0.1 \\
0\end{array}$ & $\begin{array}{l}0.0 \\
9\end{array}$ & $\begin{array}{l}0.1 \\
1\end{array}$ & $\begin{array}{l}0.1 \\
5\end{array}$ & $\begin{array}{l}0.0 \\
2\end{array}$ & $\begin{array}{l}0.0 \\
7\end{array}$ & $\begin{array}{l}0.0 \\
9\end{array}$ & $\begin{array}{l}1.0 \\
3\end{array}$ & $\begin{array}{l}0.1 \\
3\end{array}$ & $\begin{array}{l}0.0 \\
8\end{array}$ & $\begin{array}{l}0.0 \\
6\end{array}$ & $\begin{array}{l}0.0 \\
8\end{array}$ & $\begin{array}{l}0.0 \\
5\end{array}$ & $\begin{array}{l}0.1 \\
1\end{array}$ & $\begin{array}{l}0.0 \\
9\end{array}$ & $\begin{array}{l}0.0 \\
7\end{array}$ & $\begin{array}{l}0.0 \\
4\end{array}$ \\
\hline $\begin{array}{l}\text { B1 } \\
0\end{array}$ & $\begin{array}{l}0.0 \\
3\end{array}$ & $\begin{array}{l}0.1 \\
1\end{array}$ & $\begin{array}{l}0.1 \\
1\end{array}$ & $\begin{array}{l}0.0 \\
7\end{array}$ & $\begin{array}{l}0.0 \\
5\end{array}$ & $\begin{array}{l}0.0 \\
1\end{array}$ & $\begin{array}{l}0.1 \\
4\end{array}$ & $\begin{array}{l}0.0 \\
2\end{array}$ & $\begin{array}{l}0.0 \\
3\end{array}$ & $\begin{array}{l}1.0 \\
6\end{array}$ & $\begin{array}{l}0.1 \\
0\end{array}$ & $\begin{array}{l}0.0 \\
4\end{array}$ & $\begin{array}{l}0.0 \\
9\end{array}$ & $\begin{array}{l}0.1 \\
3\end{array}$ & $\begin{array}{l}0.0 \\
6\end{array}$ & $\begin{array}{l}0.0 \\
4\end{array}$ & $\begin{array}{l}0.0 \\
5\end{array}$ & $\begin{array}{l}0.0 \\
3\end{array}$ \\
\hline
\end{tabular}


A DEMATEL Method to Analyze the Barriers of Supply Chain Management in Food Processing Industry

\begin{tabular}{|c|c|c|c|c|c|c|c|c|c|c|c|c|c|c|c|c|c|c|}
\hline $\begin{array}{l}\text { B1 } \\
1\end{array}$ & $\begin{array}{l}0.0 \\
5\end{array}$ & $\begin{array}{l}0.1 \\
0\end{array}$ & $\begin{array}{l}0.0 \\
7\end{array}$ & $\begin{array}{l}0.0 \\
9\end{array}$ & $\begin{array}{l}0.1 \\
2\end{array}$ & $\begin{array}{l}0.0 \\
2\end{array}$ & $\begin{array}{l}0.1 \\
5\end{array}$ & $\begin{array}{l}0.0 \\
7\end{array}$ & $\begin{array}{l}0.0 \\
5\end{array}$ & $\begin{array}{l}0.0 \\
8\end{array}$ & $\begin{array}{l}1.0 \\
5\end{array}$ & $\begin{array}{l}0.0 \\
5\end{array}$ & $\begin{array}{l}0.1 \\
6\end{array}$ & $\begin{array}{l}0.0 \\
8\end{array}$ & $\begin{array}{l}0.0 \\
7\end{array}$ & $\begin{array}{l}0.0 \\
4\end{array}$ & $\begin{array}{l}0.0 \\
5\end{array}$ & $\begin{array}{l}0.0 \\
4\end{array}$ \\
\hline B1 & 0.0 & 0.1 & 0.0 & 0.0 & 0.1 & 0.0 & 0.0 & 0.0 & 0.0 & 0.1 & 0.1 & 1.0 & 0.1 & 0.0 & 0.0 & 0.0 & 0.0 & 0.0 \\
\hline 2 & 3 & 2 & 9 & 7 & 5 & 2 & 7 & 3 & 4 & 5 & 1 & 4 & 3 & 9 & 7 & 4 & 7 & 6 \\
\hline B1 & 0.0 & 0.0 & 0.1 & 0.0 & 0.1 & 0.0 & 0.1 & 0.0 & 0.0 & 0.0 & 0.0 & 0.1 & 1.0 & 0.0 & 0.0 & 0.0 & 0.0 & 0.0 \\
\hline 3 & 3 & 9 & 1 & 7 & 0 & 1 & 4 & 3 & 5 & 8 & 7 & 0 & 7 & 6 & 9 & 4 & 9 & 4 \\
\hline B1 & 0.0 & 0.1 & 0.1 & 0.0 & 0.0 & 0.0 & 0.1 & 0.0 & 0.0 & 0.1 & 0.1 & 0.0 & 0.1 & 1.0 & 0.0 & 0.0 & 0.1 & 0.0 \\
\hline 4 & 3 & 1 & 5 & 9 & 7 & 2 & 6 & 3 & 3 & 6 & 2 & 9 & 7 & 6 & 6 & 6 & 0 & 6 \\
\hline B1 & 0.0 & 0.1 & 0.1 & 0.1 & 0.1 & 0.0 & 0.1 & 0.0 & 0.0 & 0.1 & 0.1 & 0.1 & 0.1 & 0.1 & 1.0 & 0.1 & 0.1 & 0.0 \\
\hline 5 & 4 & 3 & 3 & 6 & 7 & 2 & 2 & 4 & 4 & 8 & 6 & 2 & 9 & 3 & 7 & 0 & 3 & 7 \\
\hline B1 & 0.0 & 0.1 & 0.0 & 0.0 & 0.1 & 0.0 & 0.0 & 0.0 & 0.0 & 0.1 & 0.1 & 0.0 & 0.1 & 0.1 & 0.0 & 1.0 & 0.0 & 0.0 \\
\hline 6 & 5 & 1 & 9 & 7 & 0 & 1 & 7 & 5 & 3 & 2 & 4 & 6 & 1 & 0 & 6 & 4 & 6 & 3 \\
\hline B1 & 0.0 & 0.0 & 0.0 & 0.0 & 0.0 & 0.0 & 0.0 & 0.0 & 0.0 & 0.0 & 0.0 & 0.0 & 0.0 & 0.0 & 0.0 & 0.0 & 1.0 & 0.0 \\
\hline 7 & 2 & 8 & 7 & 7 & 6 & 1 & 9 & 6 & 4 & 4 & 3 & 5 & 5 & 3 & 4 & 5 & 3 & 7 \\
\hline B1 & 0.0 & 0.0 & 0.0 & 0.0 & 0.0 & 0.0 & 0.0 & 0.0 & 0.0 & 0.0 & 0.0 & 0.0 & 0.0 & 0.0 & 0.0 & 0.0 & 0.0 & 1.0 \\
\hline 8 & 2 & 9 & 5 & 7 & 4 & 5 & 5 & 2 & 2 & 4 & 3 & 5 & 5 & 3 & 9 & 5 & 7 & 3 \\
\hline
\end{tabular}

Table- V: Prominence vector

\begin{tabular}{|c|c|c|}
\hline Rank & Barriers & $r w_{i}+c w_{i}$ \\
\hline 1 & B7 & 6.20 \\
\hline 2 & B5 & 5.85 \\
\hline 3 & B2 & 5.77 \\
\hline 4 & B3 & 5.67 \\
\hline 5 & B13 & 5.66 \\
\hline 6 & B15 & 5.63 \\
\hline 7 & B4 & 5.49 \\
\hline 8 & B10 & 5.26 \\
\hline 9 & B14 & 5.07 \\
\hline 10 & B1 & 5.05 \\
\hline 11 & B11 & 5.01 \\
\hline 12 & B12 & 4.71 \\
\hline 13 & B16 & 4.66 \\
\hline 14 & B17 & 4.43 \\
\hline 15 & B9 & 4.34 \\
\hline 16 & B8 & 4.07 \\
\hline 17 & B18 & 4.06 \\
\hline 18 & B6 & 3.88 \\
\hline
\end{tabular}

Table- VI. Relative vector

\begin{tabular}{|c|c|c|}
\hline Rank & Cause group & $r w_{i}-c w_{i}$ \\
\hline 1 & B1 & 1.17 \\
\hline 2 & B6 & 0.94 \\
\hline 3 & B9 & 0.54 \\
\hline 4 & B15 & 0.39 \\
\hline 5 & B7 & 0.22 \\
\hline 6 & B3 & 0.17 \\
\hline 7 & B4 & 0.13 \\
\hline 8 & B8 & 0.11 \\
\hline 9 & B14 & 0.07 \\
\hline 10 & B12 & 0.01 \\
\hline Rank & Effect group & $r w_{i}-c w_{i}$ \\
\hline 1 & B16 & -0.08 \\
\hline 2 & B2 & -0.09 \\
\hline 3 & B5 & -0.21 \\
\hline 4 & B11 & -0.31 \\
\hline 5 & B18 & -0.36 \\
\hline 6 & B17 & -0.65 \\
\hline 7 & B10 & -0.92 \\
\hline 8 & B13 & -1.12 \\
\hline
\end{tabular}

